\title{
The Role of Islamic Financial Institutions In Social Intermediary Services : Evidence In Metro City
}

\author{
Imahda Khoiri Furqon \\ IAIN Pekalongan \\ Imahdaaljihat@gmail.com \\ Fitri Kurnawati \\ IAIN Metro \\ pi2t_ajah22@yahoo.com
}

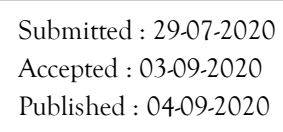

Submitted : 29-07-2020

Accepted : 03-09-2020

Published : 04-09-2020

\begin{abstract}
Islamic financial institutions are expected to be able to implement their roles as financial intermediaries and social intermediaries. But what happened in the city of Metro, the dominance of the contract on the practice of Islamic financial institutions only felt the benefits for the upper middle class. Besides that, innovative products that have not been able to reach the majority of the community are not optimal yet, where in the aggregate most of them are Muslims. So that the presence of Islamic financial institutions is considered the same as conventional, because it has not been able to answer the fundamental problems of society. Due to the limitations of researchers, the Islamic financial institutions that will be examined in this study are some Baitul Maal Wat Tamwil in Metro City. This research was conducted to analyze the strategies, procedures and product development of Islamic financial institutions in their role of social intermediation. Research is a field research with a descriptive analytical approach. Data collected using interview and documentation methods. Primary data was obtained from Islamic financial institutions (BMT) as social intermediaries in the community, namely the management and members of BMT. Secondary data were obtained from journals, research reports, books and articles. The analysis technique begins with data collection and reduction, data presentation and conclusion drawing. The results of this study are the role of Islamic financial institutions in social intermediation, namely as an intermediary that connects the aghniya and dhu'afa. The implementation procedure does not directly get commercial financing, but educational services using the tabarru agreement 'with social funds. Product development strategy, namely: establishing a special division in Islamic financial institutions and collaborating with social institutions around.
\end{abstract}

Keywords: Social intermediation, Sharia Financial Institutions, Baitul maal wat tamwil, the role of financial institutions.

\section{A. Introduction}

Positive upward trends experienced by Islamic financial institutions. Although in the aggregate market share of Islamic financial institutions is still 
relatively small when compared to the market shares of other financial institutions. Sharia financial institutions are all bodies or institutions that through their activities in the financial sector draw funds from and distribute them to the public (Siringoringo, n.d.). Still according to Siringoringo, the main function of banking is financial intermediation, which is a process of buying excess funds from business actors, both the government and households, to be channeled to other economic players that are in deficit. The financial intermediary function arises due to the high cost of monitoring, liquidity costs, and price risk due to asymmetric information between the owner of the fund and the user of the fund, so an intermediary is needed to accommodate the needs of both parties.

In theory, the role of Islamic financial institutions is not limited to financial intermediation. But there is also the role of social intermediation as an institution that arises due to the existence of muamalah transactions in it to realize justice (Karim, 2010). Social Intermediation is a process whereby the investment is formed by the development of human resources and capital institutions, to increase the confidence of the community, as a preparation for them in using formal financial intermediation (Antonio \& Nugraha, n.d.).

One form of shari'ah financial institutions in the city of Metro is shari'ah banking, shari'ah financial services cooperatives, and shari'ah pawnshops. The main activities of sharia banking (raising funds, channeling funds, and providing services), which are reflected through third-party funds collected and financing provided, shows that the growth ratio reaches $40 \%$ per year for greater than the movement of conventional banking in the last two decades this. Shariah pawnshop is not very popular in this Metro city. Shari'ah financial services cooperatives or often referred to by people with BMTs are quite popular in the Metro community after shari'ah banking.

However, Islamic financial institutions that exist in society today are not considered capable of moving to the true nature of Islamic financial institutions. Shariah financial institutions as one of the tangible forms of financial institutions with an Islamic economic system should be directed towards the full objectives of Islamic economics, namely Falah (making the benefit of the world and the hereafter). Where basically shari'ah financial institutions benefit can be felt by all groups of people, both from the middle to upper-class society or the community (community). In the original language (Arabic) the word community is taken from the word sakana which means silent or calm, while the word masakin is a form of jama' from society which according to the language is taken from the word sakana which means to be silent or immobile because of physical weakness or a patient and qana'ah (Gazalba, 1985).

As happened in the city of Metro that the dominance of non-profit sharing agreements (murabaha) on the practice of Islamic financial institutions that can only be felt for the benefit of the upper-middle class with above-average income. Besides, the innovative products of shari'ah financial institutions are not yet optimal which 
can touch the majority of the community, wherein the aggregate most of them are Muslims. So in the end the presence of Islamic financial institutions is considered not much different from conventional financial institutions, because its presence has not been able to answer the problems of the community fundamentally (community). This role should be felt by all sections of society. As the main role of Islamic financial institutions in addition to financial intermediation is also as social intermediation. The Shari'ah Financial Institution that will be the focus of this research is the Shari'ah cooperative (BMT / Baitul maal wat tamwil) in the city of Metro.

Islamic financial institutions are expected to be able to implement their role as financial intermediaries and social intermediaries. But what happened in the city of Metro, the dominance of the contract on the practice of Islamic financial institutions only felt the benefits for the upper-middle class. Besides that, innovative products that have not been able to touch the majority of the community are not optimal yet, wherein the aggregate most of them are Muslim. So that the presence of Islamic financial institutions is considered the same as conventional, because it has not been able to answer the fundamental problems of society. Due to the limitations of research, the Islamic financial institutions that will be examined in this study are some Baitul Maal Wat Tamwil in Metro City.

\section{B. Literature Review}

\section{The Effort of Islamic Financial Institutions in Implementing Social Intermediation}

In implementing its role as social intermediation, BMT carries out economic empowerment for the community. Community economic empowerment carried out by BMT involves three main elements of empowerment, namely empowerment strategies, empowerment techniques, and empowerment conditioning. The three elements of empowerment are implemented with real activities in the form of segmentation of powerless and helpless customers, tiered financing treatment, intensive guidance, provision of human resources who understand the vision and mission of empowerment, optimization of economic and social intermediation functions, and motivation and provision of facilities coordinated saving.

Social funds are collected from members in the form of zakat, donations or alms. Even in one Baitul Maal in Lampung has a special division to manage endowment funds. It's just that the role of social intermediation has not been maximized because it is deeply hampered by existing human resources and social funds. But there is one thing that can be underlined by all BMTs in Metro City in terms of social intermediation, namely the existence of qadrul hasan financing, where this financing is intended for BMT members who have financial difficulties (cannot provide profit sharing or provide margins to BMT parties due to circumstances). 
The economic empowerment of the community through qadrul hasan financing by BMT is carried out through regular and directed stepping, as follows:

1. Intensive interaction with the surrounding community,

2. Cultivation of consciousness or similarity of mind,

3. Formation of coordinated groups,

4. Intensive coaching,

5. Active participation, and

6. Active actors in the sustainability of empowerment.

Thus BMT from the beginning must establish a vision and mission of empowerment and promote dialogue to the community to find problems and solutions from the community itself. BMT management should provide human resources who understand the vision and mission of community economic empowerment. BMT work patterns are rational work patterns. Customer motivation leads to consideration of primordial rational and ideological actions, not intellectual or traditional. The function of economic intermediation and social intermediation is carried out by always maximizing human resources and utilizing the factors of production that are around BMT.

BMT also emphasizes the type of profit-sharing financing to compensate for the amount of financing with buying and selling patterns or muraba. Therefore BMT management must make guidance directed to customers so that the BMT coaching and balancing functions can be carried out properly.Social intermediation is one of the important roles of sharia financial institutions. Apart from the role of financial intermediation. Islamic financial institutions have tried their best to maximize their role in social intermediation.

The efforts made by Islamic financial institutions in Metro City to carry out their role in social intermediation are:

1. Development of the economic potential of the people,

2. Improving the quality of human resources,

3. Intermediaries aghniyâ and dhu'afâ ',

4. Intermediaries of fund owners and users of funds

The function of BMT is not just as a partner or intermediary institution, but is closer to the coaching function for customers.

\section{Obstacles to the Role of Social Intermediation for Communities in Metro City}

In carrying out its role as social intermediation, some obstacles cannot be considered easy. These obstacles include:

1. People who lack access to Islamic financial institutions

Basically there are two interrelated objectives of financing to Islamic financial institutions, namely as follows: 
a. Profitability, which is the goal to obtain results in the form of benefits achieved.

b. Safety, security from the achievements or facilities provided must be guaranteed so that the goal of profitability can be truly achieved without significant obstacles.

In other languages, for sharia financial institutions this financing activity does not merely contain elements that aim to provide the impetus for the development of community economic activities by providing financing in the form of funds alone, but also becomes an element that generates income.

Besides, this goal can be seen according to the main actors involved in lending, including clearer goals or motives for Islamic financial institutions. For this reason, sharia financial institutions must be able to carry out the selection function in setting their lending targets. Thus, only providing credit to business sectors that are feasible and bankable (have an understanding of banking activities), so that the community is never involved as a target market (market segmentation) in its activities. In this regard, the financial theory states that the risk of financing to the community is caused by several factors, namely:

a. High asymmetric information (information that is not in line),

b. The existence of community moral hazard,

c. The existence of adverse selection problems from the community, and

d. Lack of an element of trust (trust) banking for the community; so that any financial institution will not involve the public in financing activities.

2. Society has information that is not in line

The existence of the community when being part of the target market (market segmentation) of Islamic financial institutions experiencing asymmetric information problems (information that is not in line), for example in the process of finding, supervising, or applying the costs (funds) needed. This is related to the inability of the borrower (the public) to oversee the demand and accumulation of loans in small amounts, causing transaction costs to increase.

3. Society is considered to have moral hazard

Moral Hazard looks at the internal state of the community concerned, where the community is seen as a group that does not have personal capabilities regarding banking (not bankable), such as: not having a systematic record related to its business, not having a clear business plan, and only burdened by the need for a relatively small source of business funds.

More than that, the community does not have a guarantee nor is it supported by guarantors who can provide guarantees as well. This is based 
on the business carried out by the community more to the type of business that generates income (profit) is relatively small, while the risk of loss from the business carried out is also uncertain.

4. The Problem of Adverse Selection from the Community

The problem of Adverse selection is understood as a condition of society that has physical and non-physical (socio-economic) obstacles that trigger market failure. Includes factors such as weak infrastructure, remote geographical location (hard to reach), inability to read and write, low health (eg malnutrition), and dogmas that marginalize tribal, cultural and gender values.

\section{Research Methodology}

This research is field research conducted in an intensive, detailed, and indepth manner on the object of research. The object of study in this study is the role of shari'ah financial institutions in social intermediation, so the role of shari'ah financial institutions social intermediation is focused on the role of institutions (BMT) in social intermediation for the people of the Metro city. The approach used in this research is analytical descriptive. So in this study, the research was conducted as an effort to collect data in the city of Metro that has a relationship with the role of Islamic financial institutions in social intermediation in the city of Metro. Data collected using interviews and documentation methods. Primary data were obtained from Islamic financial institutions (BMT) as social intermediaries in the community, namely the management and members of BMT. From the management, there are 3 marketing people and from the members, there are 6 people. Secondary data were obtained from journals, research reports, books, and articles. The analysis technique begins with data collection and reduction, data presentation, and conclusion drawing.

\section{Discussion}

Based on the results of the study, BMT is included in the empowering category, because in the application of social intermediation, BMT has not been maximized, BMT focuses on the financing stage only. If bad financing occurs, BMT only provides solutions that motivate members to better manage finances and BMT provides a grace period to pay off according to mutual agreement.

In the theory of social intermediation, BMTs should be able to do better social intermediation with a saving stage that protects members by providing funds so that members' businesses can run further. In the Baitul Maal program, BMT is still lacking in empowering its members, BMT is more focused on its Baitul Tamwil, BMT should be able to empower both sides of Baitul Maal and Baitul Tamwil.

Baitul Maal zakat fund on BMT is Rp. 0, while the Baitul Tamwil BMT fund is around Rp. 60 billion, from this it is clear that BMT only focuses on the 
commercial sector or its business. BMT conducts activities on the Baitul Maal side only at certain times, such as donations to Palestinian citizens, giving groceries in the month of Ramadan, and giving donations to the mosque. BMT should be more concerned with the surrounding community than other residents, because there are still many people around who are still lacking / needy. And even better if giving funds to people who are less able to be able to try to make more empowered like making small businesses, which from here can get profit and the money can spin well, so that the funds provided are not free just given away, but it produces profitable results through the way the funds are processed while fostered with a business or selling small. Can be seen from three side, as follows:

1. Creating an atmosphere or climate that enables the potential of developing societies (enabling), because there is no society at all without power, social intermediation is an effort to build that power, by encouraging motivating and raising awareness of its potential and striving to develop it;

2. Strengthening the potential or power possessed by the community (empowering) that requires positive steps, apart from just creating the climate and atmosphere, including concrete steps, and concerning providing various inputs, as well as opening access to various opportunities ) which will make the community more empowered; and

3. Empowerment also means to protect (saving), namely by providing protection and partiality to the weak, but protecting does not mean isolating or covering up from interactions, because protecting is an effort to prevent unequal competition, as well as strong exploitation of the weak.

When viewed from the theory that there is no BMT participation in social intermediation both in terms of maal and regional Tamwil. The role of BMTs in the social intermediation of small and medium business communities is still lacking because it only focuses on providing financing. Like the activities carried out by BMT only focus on financing with the contract Qadrul hasan. So BMT helps small and medium businesses only by helping through the commercial sector. Besides, the obstacle that is still an obstacle for BMT in its role for micro business is that it is still often difficult for members to apply bookkeeping, so that microbusinesses are still less effective in carrying out the business. In addition, the social mediation conducted by BMT is not yet entirely for the welfare of the members because social intermediation is only limited to financing and has not yet reached the saving stage, which is protecting its members in the event of non-performing financing. BMT should be able to empower people with the saving stage, because BMT is included as the largest Islamic financial institution in Lampung, so members can be nurtured and protected by BMT from things that are not desirable.

For this reason, a strategy is needed to be able to maximize the role of BMT in social intermediation, including:

1. Establish a Special division to handle existing social funds to optimize the role of social intermediation. This is based on the assumption that the 
implementation of the role of social intermediation is an activity that is different from the main activities of other BMT.

2. Collaboration with other social institutions to facilitate segmentation in the role of social intermediation.

The steps and strategies to eliminate the negative stigma of the existence of shari'ah financial institutions that are ongoing, namely through the firmness of the position of shariah financial institutions that should be able to provide broader benefits than just pursuing the halal transaction or profit, but have a greater role in society as a manifestation of the teachings Islam that is concerned with issues of income inequality, social alleviation, and social justice. As the purpose of this Islamic economy is the achievement of falah (prosperity in the world and the hereafter) for all humans.

\section{E. Conclusion}

The results of this study are the role of Islamic financial institutions in social intermediation, namely as an intermediary that connects aghniya 'and dhu'afa. The process of implementing the role of shari'ah financial institutions in social intermediation ie that the community does not directly obtain commercial financing, but must be provided with educational services using the tabarru agreement 'using social funds; zakat, infaq, sadaqah, endowments and grants (ZISWAH). In this context, Islamic banking as a manifestation of Islamic values with the ZISWAH instrument can be an alternative solution to meet the basic needs of the poor, and can even be used as additional capital in conducting productive business activities. Product development strategies that can be implemented to develop the role of Islamic financial institutions in social intermediaries towards the community are: establishing a special division in Islamic financial institutions, then cooperating with existing social institutions.

\section{Bibiliography}

Aliminsyah, Padji. (2016) Kamus Istilah Keuangan dan Perbankan, Bandung:Yrama Widya.

Amalia, Euis. (2005) Sejarah Pemikiran Ekonomi Islam dari Masa Klasik Hingga Kontemporer, Jakarta : Pustaka Asatrus.

Antonio, Muhammad Syafi'I. (2004) Bank Syariah dari Teori ke Praktek, (Jakarta : Gema Insani.

Antonio, Syafi'i \& Nugraha, Hilman F. (2013) Peran Intermediasi Sosial Perbankan Syari'ah bagi Masyarakat, Jurnal Tsaqafah, Volume 9 Nomor 1.

Arifin, Johan. (2013) Hubungan Hukum Kemitraan dalam Linkage Program Perbankan Syari'ah, Jurnal Economica, Volume 4 Nomor 2, 2013

Blinder, Alan. (2007) Hard Heads, Soft Hearts : Tough Minded Economics for a Just Society, M. A. Edison Wesley. 
Boediono. (2009) Ekonomi Makro, Yogyakarta: BPFE.

Boediono. (2009) Seri Sinopsis Pengantar Ilmu Ekonomi No. 5: Teori Moneter, Yogyakarta: BPFE.

Dimyati, Ahmad. (2008) Teori Keuangan Islam Rekonstruksi Metodologis Terhadap Teori Keuangan Al-Ghazali. Yogyakarta: UII Press.

El Diwany, Tarek. (2003) The Problem with Interest (Sistem bunga dan Permasalahannya), Jakarta: Akbar.

Huda, Nurul. (2018) et al., Ekonomi Makro Islam, Jakarta: Kencana.

Kahf, Monzer. (2015) Ekonomi Islam (Telaah Analitik terhadap Fungsi Sistem Ekonomi Islam), Yogyakarta: Pustaka Pelajar.

Karim, Adiwarman A. (2007) Ekonomi Makro Islami, Jakarta, PT. Raja Grafindo Persada.

Karim, Adiwarman A. (2006) Sejarah Pemikiran Ekonomi Islam, (Jakarta : Raja Grafindo Persada.

Mankiw, N. Gregory. (2007) Macro Economics, USA : Worth Publishers.

Mujiono, Slamet. (2017) Eksistensi Lembaga Keuangan Mikro : Cikal Bakal LahirnyaBMT di Indonesia, Jurnal al Masraf, Volume 2 Nomor 2.

Ridwan, M. (2013) Ekonomi Makro dan Mikro Islam, Jakarta : Citapustaka Media.

Rofiah, Khusniati. (2011) Peran Lembaga Keuangan Mikro dalam Pemberdayaan Ekonomi Masyarakat di Kabupaten Ponorogo, Volume 5 Nomor 1, Jurnal Kodikisia.

Saeed, Abdullah. (2003) Islamic Banking and Interest A Study of the Prohibition of Riba and its Contemporary Interpretation, Terj. Muhammad Ufuqul Mubin, et al, "Bank Islam dan Bunga: Studi Kritis Larangan Riba dan Interpretasi Kontemporer", Yogyakarta: Pustaka Pelajar.

Setiawan, Aziz Budi. (2006) Perbankan Syariah; Challenges dan Opportunity Untuk Pengembangan di Indonesia, Jurnal Kordinat, Edisi: Vol. VIII No. 1.

Sholahuddin, M. (2006) Lembaga Ekonomi Keuangan $\mathcal{E}$ Keuangan Islam, Muhammadiyah University Press, Surakarta.

Sitompul, Zulkarnain. (2002) KemungkinanPenerapan Universal Banking System di Indonesia, jurnal Hukum Bisnis, Volume 20, Agustus-September.

Smith's, Adam (2009) The Wealth of Nations, UK: Infinite Ideas Limited.

Sriyana, Jaka \& Raya, Fitri. (2013) Peran BMT dalam Mengatasi Kemasyarakatan di Kabupaten Bantul, Jurnal Inferensi, Volume 7 Nomor 1.

Sudarsono, Heri. (2002) Konsep Ekonomi Islam Suatu Pengantar, Yogyakarta : Ekonissia.

Sugiono. (2008) Metode Penelitian Kualitatif Kuantitatif, Bandung : Alfabeta.

Sukirno, Sadono. (2000) Makro EKonomi, Jakarta :Raja Grafindo Persada.

Subaki, Ahmad et.al. (2011) Pengaruh Modal Sosial terhadap Kinerja Lembaga Keuangan Mikro Syari'ah (LKMS) dan Kesejahteraan Masyarakat pada LKMS di Pondok 
Pesantren al Islah Kabupaten Cirebon Jawa Barat, Seminar Internasional Dan Call For Papers "Towards Excellent Small Business, Yogyakarta.

Sukardi, Budi. (2016) Inklusivisme Maqasid Syari'ah Menuju Pembangunan Berkelanjutan Bank Syari'ah di Indonesia, Jurnal Tsaqafah, Volume 12 Nomor 1.

Triandaru, Sigit. (2000) Ekonomi Makro Pendekatan Kontemporer, Jakarta : Salemba Empat.

Wirdyaningsih et. al. (2005) Bank dan Asuransi Islam di Indonesia, Kencana, Jakarta.

Yusanto, Ismail. (2001) Mencari Solusi Krisis Ekonomi. Dalam buku Dinar Emas Solusi Krisis Moneter, Jakarta: PIRAC, SEM Institute, Infid. 